\title{
Quantification of Tannins from Curupay Bark
}

\author{
Thaís Brito Sousa ${ }^{1}$ (D), Sebastião Gabriel Souza ${ }^{1}$ (D), \\ Thayane Batistão Bondioli Franco ${ }^{1}$ (D), Márcia Silva de Jesus ${ }^{2}$ (D), \\ Fabio Akira Mori ${ }^{1}$
}

${ }^{1}$ Departamento de Ciências Florestais, Universidade Federal de Lavras - UFLA, Lavras/MG, Brasil ${ }^{2}$ Departamento de Engenharia Florestal, Universidade Federal de Viçosa - UFV, Viçosa/MG, Brasil

\begin{abstract}
This study aimed to assess the influence of time and sodium sulfite concentration on tannin yield in Curupay bark and propose better extraction conditions. The extractions were performed using $100 \mathrm{~g}$ of dried bark and $1500 \mathrm{~mL}$ of water at $70^{\circ} \mathrm{C}$, with extraction times of 2,3 , and $4 \mathrm{~h}$ and amount of extractor salt at the concentrations of $0,1,2,3$, and $4 \%$. The following parameters were evaluated: content of total solids, total yield of solids, Stiasny index, and gravimetric yield of condensed tannins and non-tannins. Results show that the higher the concentration of sodium sulfite, the higher the content and yield of solids, as well as the higher the extraction of non-tannin compounds. Three-hour extraction time at $3.0 \%$ sodium sulfite concentration was the best condition to extract tannins from Curupay bark, under which a condensed tannin yield of $20.46 \%$ was obtained.
\end{abstract}

Keywords: Anadenanthera peregrina, Stiasny index, extraction. 


\section{INTRODUCTION}

Utilization of wood waste, including tree bark, as a means of obtaining compounds for industrial use has recently been in the news.

One of these compounds is tannin, which represents the second largest group of phenolic compounds found in plants after lignin (Pizzi, 2003). When extracted from plants, these polyphenols present a variety of uses, with tanning of animal hides as the best known. However, they are also very useful in the pharmaceutical industry, especially on account of their antioxidant and antimicrobial properties (Deng et al., 2016; Zarin et al., 2016); in the food industry, where they are present in wine production, as they are one of the most abundant substances in different parts of grapes (Ashok \& Upadhyaya, 2012); in the wood adhesives industry, in which Pizzi (1983) emphasizes their reactivity with formaldehyde; as well as in water treatment, where they perform a coagulating function (Beltrán-Heredia et al., 2009).

Although plant tannins is a biodegradable product obtained from wood industry waste at low cost, one of the major problems in using them is the lack of knowledge about the best way to extract them from different species, because of the variability in their structure and chemical composition is very high. In addition, there are few studies in this respect due to the complexity in performing some characterization techniques, as well as because many studies focus on the product already extracted in order to apply it to different fields. Thus, studies are required to adapt the extraction conditions for each species, respecting their specific characteristics.

Several points should be considered when extracting tannins, such as the choice of the extractor salt, because its concentration and extraction time are fundamental for obtaining a quality product. Many studies have reported sodium sulfite as one of the most appropriate salts for this purpose, as it increases the contact surface between the tannins and the solvent, enhancing extraction efficiency (Mori et al., 2003; Chupin et al., 2013). Nevertheless, high salt concentrations associated with long extraction times can depreciate the levels of tannins and bioactive compounds, whereas very low concentrations and/or short times can result in low returns from the forestry material (Aires et al., 2016).
Species of the Brazilian Cerrado, especially those of the Fabaceae family, have been shown to be promising sources of tannins for a variety of uses, given the high gravimetric yield found in various parts of the tree. Stryphnodendron adstringens, known as stryphnodendron barbatiman, shows a high quantity of these phenolic compounds in its bark, with a higher average amount compared with those of other commercially exploited species, such as black wattle (Acacia mearnsii) (Mori et al., 2003).

Another species that stands out as a producer of tannins is Anadenanthera peregrina, popularly known as Curupay. The bark of this leguminous plant produces good yields of condensed tannins, a class of tannins widely found in nature and whose composition includes flavonoid units linked by carbon-carbon bonds that are difficult to break using hydrolyses, in addition to having a strong nucleophilic character (Pizzi, 1982; Sartori et al., 2014a). This is one of the reasons why the tannins of this species are suitable for use as raw material in the production of wood adhesives (Carneiro et al., 2009).

Anadenanthera peregrina is a leading species whose wood is very dense, hard, and of average texture (Lorenzi, 1998). The bark of the Curupay tree is one of the main non-wood industry products found in the Cerrado region, and its use for extraction of tannins is economically viable because they present various application, adding greater value to the bark, resulting in higher returns from this waste (Afonso, 2009; Sartori et al., 2014a).

In light of the foregoing, the purpose of this study was to evaluate the influence of extraction time and sodium sulfite concentration on yields of condensed tannins in Curupay (Anadenanthera peregrina) bark and propose better extraction conditions.

\section{MATERIAL AND METHODS}

\subsection{Collection and preparation of the material}

The bark of 10 Curupay (Anadenanthera peregrina (L.) Speg.) trees with average diameter at breast height (DBH) of $19 \mathrm{~cm}$ were used in this study as raw material for tannin extraction. The plants were harvested in a native forest located in the municipality of Barreiras, Bahia state, Brazil. Climate in the region is Aw 
according to the Köppen classification. Average annual temperature and rainfall are $24.9^{\circ} \mathrm{C}$ and $1045 \mathrm{~mm}$, respectively (The National Meteorological Institute of Brasil - INMET, 2015).

Bark was collected using machetes, and dimension was reduced to $30-40 \mathrm{~cm}$ to facilitate transportation and handling. Subsequently, they were dried in open air for three weeks and ground using a hammer mill to obtain a finer, more uniform material.

Humidity of the material was obtained in quintuplicates to initiate extraction of the tannins. $20 \mathrm{~g}$ of ground bark were removed and placed in a drying oven at $103 \pm 2{ }^{\circ} \mathrm{C}$ for $24 \mathrm{~h}$. Humidity was calculated based on Brazilian Regulatory Standard NBR 7190, Brazilian Technical Standards Association - ABNT (1997).

\subsection{Extraction of the tannins and calculation of the yield of total solids}

Tannins were extracted by adapting the methodology used by Mori et al. (2003). Extractions were performed in water bath using $100 \mathrm{~g}$ of absolutely dry bark and $1500 \mathrm{~mL}$ of water (a liquid-to-bark ratio of 15:1) at $70{ }^{\circ} \mathrm{C}$ under different conditions of time and quantities of sodium sulfite $\left(\mathrm{Na}_{2} \mathrm{SO}_{3}\right)$. Extractions times were 2, 3 , and 4 hours. The quantities of sodium sulfite used were $0,1,2,3$, and $4 \%$ in relation to bark dry mass.

After extraction, the material was filtered using a fine cloth strainer and the residue was discarded. Next, the liquid obtained was strained through a 200-mesh colander and filtered using a vacuum pump and a sintered glass filter (porosity 2) lined with glass wool. The filtrate was concentrated through evaporation to the volume of $150 \mathrm{~mL}$ on a heating plate.

After concentration of the filtrate, the mass of the extract was obtained and two $10 \mathrm{~g}$ samples were collected. They were then placed in oven for $24 \mathrm{~h}$ at a temperature of $103 \pm 2{ }^{\circ} \mathrm{C}$ and the dry mass was subsequently obtained. The percentage content of solids was obtained using Equation 1. To calculate the yield of total solids, the content of solids (g) was multiplied by the mass of each extract.

$$
\operatorname{TST}(\%)=\left(\frac{M s}{M u}\right) \times 100
$$

where: $\operatorname{TST}(\%)=$ percentage content of solids; Ms = dry mass of sample (g); $\mathrm{Mu}=$ humid mass of the sample ( $\mathrm{g}$ ).

\subsection{Determination of yield in condensed tannins and non-tannin components}

Samples of $20 \mathrm{~g}$ were collected from the concentrated liquid to determine the Stiasny index. According to Guangcheng et al. (1991), this can be obtained from the reaction between $20 \mathrm{~g}$ of the concentrated extract, $10 \mathrm{~mL}$ of distilled water, $4 \mathrm{~mL}$ of formaldehyde $(37 \%, \mathrm{~m} / \mathrm{m})$, and $2 \mathrm{~mL}$ of $\mathrm{HCl} 10 \mathrm{~N}$. This mixture was heated for $35 \mathrm{~min}$ under reflux and, after the reaction had ended, the material was filtered in a sintered glass filter (porosity 2) and placed in oven at $103 \pm 2{ }^{\circ} \mathrm{C}$ until a constant mass was reached. Upon obtaining the dry mass from the precipitate, the Stiasny index was calculated using Equation 2.

$\cdot I S=\left(\frac{m 1}{m 2}\right) \times 100 \cdot$

where: IS = Stiasny index (\%); $\mathrm{m} 1=$ dry mass of the tannin-formaldehyde precipitate; $\mathrm{m} 2=$ total mass of solids in $20 \mathrm{~g}$ of extract.

The gravimetric yield in condensed tannins (\%) was obtained according to Equation 3 and the yield of non-tannin components using was calculated using Equation 4.

$\mathrm{RTC}=R S T \times \mathrm{IS}$

where: RTC = gravimetric yield in condensed tannins (\%); RST $=$ yield of total solids (\%); IS = Stiasny index (\%).

$\mathrm{RNT}=R S T-\mathrm{RCT}$

where: RNT $=$ yield of non-tannin components; RST $=$ yield of total solids (\%); RTC = gravimetric yield of condensed tannins (\%).

\subsection{Analysis of the data}

The experiment was conducted in a totally randomized design containing 15 treatments and three repetitions in a $3 \times 5$ factorial design, namely, three conditions of extraction time (2, 3, and $4 \mathrm{~h})$ and five doses of sodium sulfite $(0,1,2,3$, and $4 \%$ in relation to bark dry mass).

The results obtained were submitted to analysis of variance (ANOVA) using the $F$-test $(p<0.05)$ to identity differences between treatments. When present, linear and quadratic regression analysis models were applied to verify the influence of the sodium sulfite doses tested in the quantity of tannins obtained. 


\section{RESULTS AND DISCUSSION}

Prior to extraction, the bark showed mean humidity of $12.42 \%$. In the case of the parameters content of total solids, yield of total solids, and gravimetric yield of condensed tannins and non-tannins, the interaction between extraction time and sodium sulfite dosage was significant.

In the case of the content of total solids, the treatment using $3 \mathrm{~h}$ of extraction time and $3 \%$ of sodium sulfite provided the highest content mean (Table 1). Sartori et al. (2014b), assessed the gravimetric yield of condensed tannins in Anadenanthera peregrina and obtained a mean content of solids of $11.34 \%$ when performing extraction with $3 \%$ sodium sulfite for $4 \mathrm{~h}$. In the present study, the mean found for the same extraction conditions was $12.27 \%$, in line with the result observed by the aforementioned authors.

It was also verified that treatments that did not use sodium sulfite presented lower means, proving that the presence of extractor salt positively contributes to obtaining the content of total solids.

Regarding the yield of total solids (Table 2), it was observed that when salt was not used and when the concentrations were 3 and $4 \%$, the mean for $3-\mathrm{h}$ extractions were greater than those for 2 and $4 \mathrm{~h}$ extractions. It is also worth noting that, overall, the extractions performed with 3 and $4 \%$ of sodium sulfite for $3 \mathrm{~h}$ showed higher yield means, whereas extractions without salt showed much lower means when compared with those of the other treatments. This result can be explained because salt increases the surface area of the tannin chains, thus adding sulfonate groups capable of connecting hydrogen to water enhances the yield value in solids (Pizzi \& Mittal, 1994).

Based on regression analysis, similar behaviors were observed in the case of the parameters content of total solids and yield of total solids (Figures 1 and 2), in which the lowest means were observed in treatments without addition of sodium sulfite. Positive responses were observed as the dose of extractor salt increased; nevertheless, this tendency reached its limit at sodium sulfite concentrations of 6.4 and $6.8 \%$ in the case of content of total solids and yield of total solids, respectively, when the equations generated by the regression analysis were applied. As of those concentrations, the responses become negative, in accordance with the quadratic

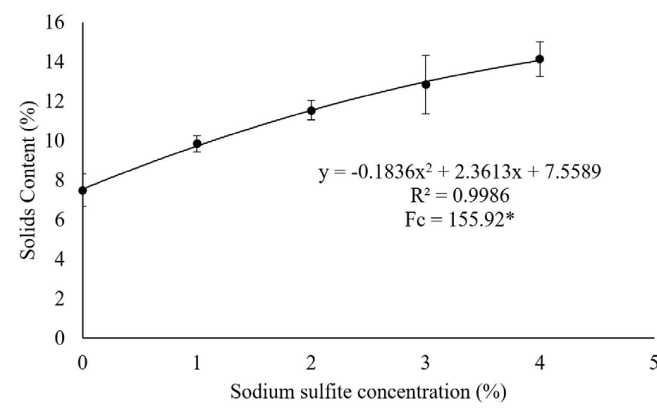

Figure 1. Content of total solids as a function of sodium sulfite concentration. ${ }^{\star}$ Significant using the $F$-test $(p>0.05)$.

Table 1. Mean values of content of total solids for concentrations of sodium sulfite used followed by the standard error of the mean.

\begin{tabular}{cccccc} 
Time (h) & \multicolumn{5}{c}{ Content of Total Solids (\%) / Sodium Sulfite (\%) } \\
\cline { 2 - 6 } & $\mathbf{0}$ & $\mathbf{1}$ & $\mathbf{2}$ & $\mathbf{3}$ & $\mathbf{4}$ \\
\hline 2 & $7.31 \pm 0.54$ & $9.94 \pm 0.90$ & $11.39 \pm 0.88$ & $12.18 \pm 0.01$ & $13.19 \pm 0.21$ \\
3 & $8.40 \pm 0.68$ & $9.40 \pm 0.23$ & $10.76 \pm 0.89$ & $14.79 \pm 0.35$ & $14.92 \pm 0.37$ \\
4 & $6.78 \pm 0.33$ & $10.22 \pm 1.19$ & $11.74 \pm 0.24$ & $12.27 \pm 0.28$ & $14.41 \pm 0.60$ \\
\hline
\end{tabular}

Table 2. Mean values of yield of total solids for concentrations of sodium sulfite used followed by the standard error of the mean.

\begin{tabular}{cccccc}
\multirow{2}{*}{ Time (h) } & \multicolumn{5}{c}{ Yield of Total Solids (\%) / Sodium Sulfite (\%) } \\
\cline { 2 - 6 } & $\mathbf{0}$ & $\mathbf{1}$ & $\mathbf{2}$ & $\mathbf{3}$ & $\mathbf{4}$ \\
\hline 2 & $10.86 \pm 0.19$ & $15.46 \pm 0.06$ & $18.42 \pm 0.15$ & $20.36 \pm 0.04$ & $21.77 \pm 0.76$ \\
3 & $13.39 \pm 0.34$ & $14.54 \pm 0.95$ & $18.99 \pm 1.05$ & $23.52 \pm 0.07$ & $24.58 \pm 0.11$ \\
4 & $11.29 \pm 0.21$ & $14.72 \pm 0.98$ & $17.50 \pm 0.01$ & $20.67 \pm 0.33$ & $21.48 \pm 0.03$ \\
\hline
\end{tabular}


polynomial model, which can be explained by the degradation of some compounds caused by the large amount of salt (Hoong et al. 2009).

No statistically significant effect on the Stiasny index was observed with increasing sodium sulfite percentage and extraction time. This parameter consists of measuring the ability of tannin samples to react with formaldehyde to create adhesives, and the literature reports that this is dependent on the mean levels of condensed tannins (Vázquez et al., 1996). Figure 3 shows that larger quantities of sodium sulfite caused

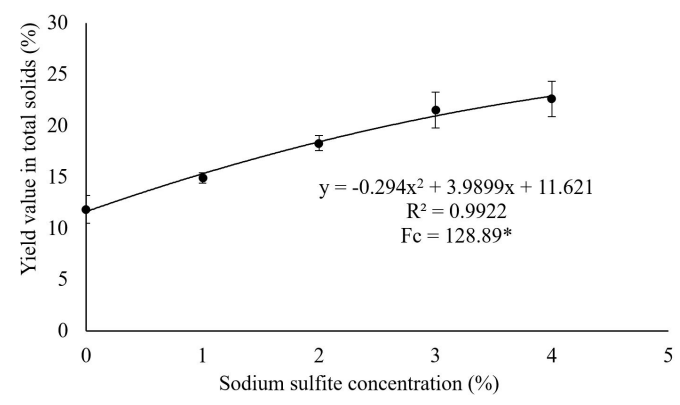

Figure 2. Yield of total solids as a function of sodium sulfite concentration. ${ }^{\star}$ Significant using the $F$-test $(p>0.05)$.

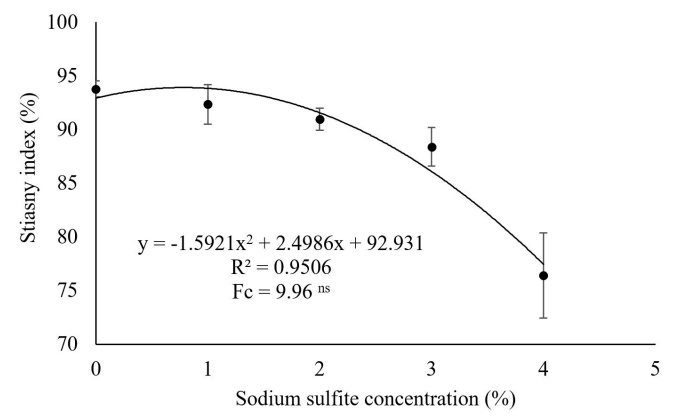

Figure 3. Stiasny index as a function of sodium sulfite concentration. ${ }^{\text {ns }}$ Not significant using the $F$-test $(p>0.05)$. the Stiasny index to fall, and it can verified that there was a larger extraction of non-tannin compounds, that is, the lower the Stiasny index, the lower the quantity of tannic substances that reacted with formaldehyde. This trend to Stiasny index reduction with increased percentages of sodium sulfite was also verified by Carneiro et al. (2007) when studying the effect of sodium sulfite on the extraction of tannins from the bark of Anadenanthera peregrina.

With respect to the gravimetric yield of condensed tannins, it can be verified (Table 3 ) that the treatment that used $3 \%$ of sodium sulfite and $3 \mathrm{~h}$ of extraction showed the highest value. This result demonstrates that low doses of extractor salt and short extraction times are not sufficient for extracting large quantities of tannins, whereas long extraction time and large salt concentrations cause depreciation of the tannins and larger extraction of non-tannin components, also resulting in lower gravimetric yields compared with those of moderate extraction conditions. These results are in agreement with those obtained by Hoong et al. (2009) and Aires et al. (2016).

Under the same conditions, Carneiro et al. (2007) found the value of $22.63 \%$, close to that obtained in this study. In a study addressing the species Stryphnodendron adstringens (stryphnodendron barbatiman), of the same family and sub-family of Anadenanthera peregrina, Mori et al. (2003) concluded that $3 \%$ of sodium sulfite, $3 \mathrm{~h}$ extraction time, at $70^{\circ} \mathrm{C}$ were the best conditions to obtain higher gravimetric yields of condensed tannins from bark.

Regression analysis (Figure 4) showed that the quadratic polynomial model was the most appropriate, indicating that there was a positive response to the application of extractor salt up to the limit of $3.6 \%$, after which the values tend to decrease.

In Table 4 and Figure 5, it can be verified that, for any extraction time, there is a tendency for the yield of

Table 3. Mean values of gravimetric yield of condensed tannins for concentrations of sodium sulfite used followed by the standard error of the mean.

\begin{tabular}{cccccc} 
Time (h) & \multicolumn{5}{c}{ Gravimetric Yield of Condensed Tannins (\%) / Sodium Sulfite (\%) } \\
\cline { 2 - 6 } & $\mathbf{0}$ & $\mathbf{1}$ & $\mathbf{2}$ & $\mathbf{3}$ & $\mathbf{4}$ \\
\hline 2 & $9.93 \pm 0.14$ & $14.61 \pm 0.02$ & $16.69 \pm 0.12$ & $18.36 \pm 0.04$ & $17.06 \pm 0.25$ \\
3 & $11.23 \pm 0.01$ & $14.07 \pm 0.67$ & $15.43 \pm 0.35$ & $20.46 \pm 0.03$ & $18.22 \pm 0.23$ \\
4 & $11.19 \pm 0.18$ & $11.31 \pm 0.37$ & $15.92 \pm 0.23$ & $17.94 \pm 0.17$ & $17.33 \pm 0.67$ \\
\hline
\end{tabular}


Table 4. Mean values of yield of non-tannins for concentrations of sodium sulfite used followed by the standard error of the mean.

\begin{tabular}{cccccc}
\multirow{2}{*}{ Time (h) } & \multicolumn{5}{c}{ Yield of Non-Tannins (\%) / Sodium Sulfite (\%) } \\
\cline { 2 - 6 } & $\mathbf{0}$ & $\mathbf{1}$ & $\mathbf{2}$ & $\mathbf{3}$ & $\mathbf{4}$ \\
\hline 2 & $0.75 \pm 0.15$ & $0.87 \pm 0.03$ & $1.47 \pm 0.25$ & $1.98 \pm 0.08$ & $5.51 \pm 0.13$ \\
3 & $0.65 \pm 0.34$ & $1.41 \pm 0.07$ & $1.75 \pm 0.05$ & $3.13 \pm 0.05$ & $6.77 \pm 0.13$ \\
4 & $0.74 \pm 0.11$ & $1.00 \pm 0.03$ & $1.56 \pm 0.24$ & $2.42 \pm 0.19$ & $4.14 \pm 0.69$ \\
\hline
\end{tabular}

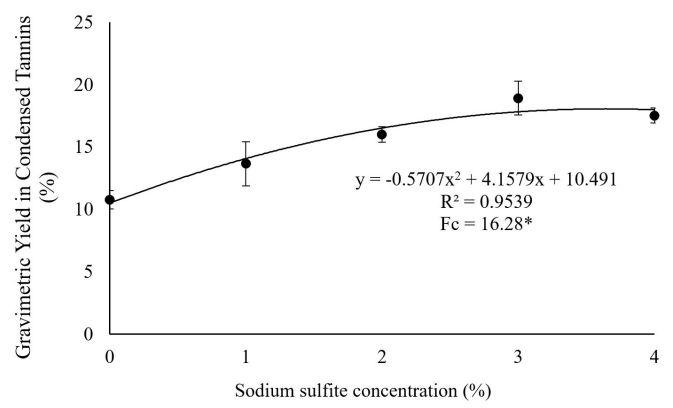

Figure 4. Gravimetric yield of condensed tannins as a function of sodium sulfite concentration. ${ }^{\star}$ Significant using the $F$-test $(p>0.05)$.

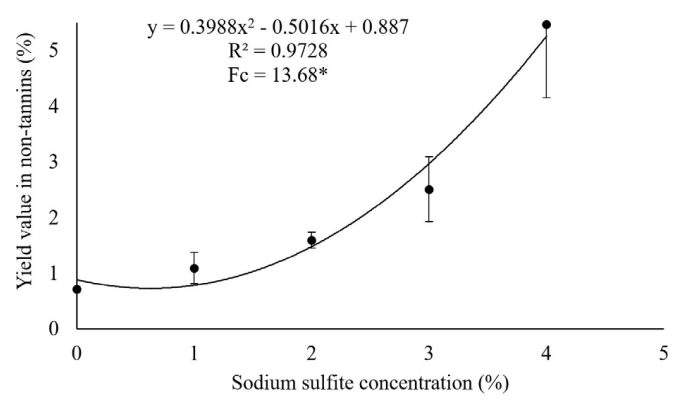

Figure 5. Yield of non-tannins as a function of sodium sulfite concentration. ${ }^{\star}$ Significant using the $F$-test $(p>0.05)$.

non-tannin compounds to increase as the quantity of sodium sulfite increases. Thus all treatments that used $4 \%$ of sodium sulfite showed higher means. Paes et al. (2013) found $10.62 \%$ for $3 \%$ of sodium sulfite and extraction time of $2 \mathrm{~h}$ assessing Anadenanthera colubrina var. cebil., whereas Sartori et al. (2014b) reported 4.07\% for $3 \%$ of sodium sulfite and an extraction time of $4 \mathrm{~h}$ analyzing the same forest species used in this study.

Figure 5 shows that the minimum yield point of non-tannins occurs at a dose of approximately $0.6 \%$, after which only positive responses are observed. Thus, it can be asserted that when high concentrations of salt are used, there is a tendency to obtain other compounds such as gums and sugars, which are of no interest, considering that tannins are not usually subjected to a purification process when extracted. Therefore, the other substances present in the tannic extract could have an adverse influence on the quality of the end product, compromising its use as raw material for the intended purpose.

\section{CONCLUSION}

The use of sodium sulfite and varied extraction times influenced the gravimetric yield of condensed tannins in the Anadenanthera peregrina species. Extraction time of $3 \mathrm{~h}$ and $3.0 \%$ sodium sulfite concentration produced the best results.

\section{ACKNOWLEDGEMENTS}

The authors are grateful to the Fundação de Amparo à Pesquisa do Estado de Minas Gerais - FAPEMIG, Coordenacão de Aperfeiçoamento de Pessoal de Nível Superior - CAPES; Conselho Nacional de Desenvolvimento Científico e Tecnológico - CNPq; and Bahia Ambiental Consultoria Ltda.

\section{SUBMISSION STATUS}

Received: 22 feb., 2016

Accepted: 25 may., 2018

\section{CORRESPONDENCE TO}

\section{Thaís Sousa}

Departmento de Ciências Florestais, Universidade Federal de Lavras - UFLA, Campus Universitário, CP 3037, Lavras, MG, Brazil e-mail: thaisbflorestal@gmail.com 


\section{FINANCIAL SUPPORT}

Fundação de Amparo à Pesquisa do Estado de Minas Gerais - FAPEMIG, Conselho Nacional de Desenvolvimento Científico e Tecnológico - CNPq.

\section{REFERENCES}

Afonso SR. Análise sócio-econômica de produtos florestais não madeireiros (PFNMs) como alternativa para a sustentabilidade do cerrado e os estudos de caso da cooperativa de catadores de pequi de Japonvar (MG). In: Bensusam N, organizador. Unindo sonhos - pesquisas ecossociais no cerrado. Brasília: Instituto de Internacional de Educação do Brasil; 2009. p. 99-113.

Aires A, Carvalho R, Saavedra MJ. Valorization of solid wastes from chestnut industry processing: Extraction and optimization of polyphenols, tannins and ellagitannins and its potential for adhesives, cosmetic and pharmaceutical industry. Waste Management (New York, N.Y.) 2016; 48: 457-464. http://dx.doi.org/10.1016/j.wasman.2015.11.019. PMid:26626811.

Ashok PK, Upadhyaya K. Tannins are astringent. Journal of Pharmacognosy and Phytochemistry 2012; 1(3): 45-50.

Associação Brasileira de Normas Técnicas - ABNT. Projeto de estruturas de madeira. Rio de Janeiro: ABNT; 1997. $107 \mathrm{p}$.

Beltrán-Heredia J, Sánchez-Martín J, Frutos-Blanco G. Schinopsis balansae tannin-based flocculant in removing sodium dodecyl benzene sulfonate. Separation and Purification Technology 2009; 67(3): 292-303. http:// dx.doi.org/10.1016/j.seppur.2009.03.039.

Carneiro ACO, Vital BR, Frederico PGU, Carvalho AMML, Vidaurre GB. Propriedades de chapas de aglomerado fabricadas com adesivo tânico de angico-vermelho (Anadenanthera peregrina) e uréia-formaldeído. Revista Árvore 2009; 33(3): 521-531. http://dx.doi.org/10.1590/ S0100-67622009000300014.

Carneiro ACO, Vital BR, Frederico PGU, Moreira AB, Dambroz CS. Efeito do sulfito de sódio na extração de tanino da casca de Anadenanthera peregrina. Floresta e Ambiente 2007; 14(1): 65-69.

Chupin L, Motillon C, Charrier-El Bouhtoury F, Pizzi A, Charrier B. Characterisation of maritime pine (Pinus pinaster) bark tannins extracted under different conditions by spectroscopic methods, FTIR and HPLC. Industrial Crops and Products 2013; 49: 897-903. http://dx.doi. org/10.1016/j.indcrop.2013.06.045.

Deng Y, Liang G, Shi Y, Li H, Zhang J, Mao X et al. Condensed tannins from Ficus altissima leaves: structural, antioxidant, and antityrosinase properties. Process Biochemistry 2016; 51(8): 1092-1099. http://dx.doi. org/10.1016/j.procbio.2016.04.022.

Guangcheng Z, Yunlu L, Yazaki Y. Extractives yields, stiasny values and polyflavonoid contents in barks from six Acacia species in Australian. Australian Forestry 1991; 3(54): 154-156. http://dx.doi.org/10.1080/00049158.199 1.10674572 .

Hoong YB, Paridah MT, Luqman CA, Koh MP, Loh YF. Fortification of sulphited tannin from the bark of Acacia mangium with phenol-formaldehyde for use as plywood adhesive. Industrial Crops and Products 2009; 30(1): 416421. http://dx.doi.org/10.1016/j.indcrop.2009.07.012.

Instituto Nacional de Meteorologia do Brasil - INMET. Estação meteorológica de observação de superfície automática [online]. Brasília: INMET; 2015 [cited 2015 Jun 9]. Available at: http://www.inmet.gov.br

Lorenzi H. Árvores brasileiras: manual de identificação e cultivo de plantas arbóreas nativas do Brasil. 2nd. ed. Nova Odessa: Instituto Plantarum; 1998.

Mori FA, Mori CLSO, Mendes LM, Silva JRM, Melo VM. Influência do sulfito e hidróxido de sódio na quantificação em taninos da casca de barbatimão (Stryphnodendron adstringens). Floresta e Ambiente 2003; 10(1): 86-92.

Paes JB, Diniz CEF, Lima CR, Bastos PM, Medeiros Neto PN. Taninos condensados da casca de angico-vermelho (Anadenanthera colubrina var. cebil) extraídos com soluções de hidróxido e sulfito de sódio. Revista Caatinga 2013; 26(3): 22-27.

Pizzi A. Condensed tannins for adhesives. Industrial \& Engineering Chemistry Product Research and Development 1982;21(3):359-369. http://dx.doi.org/10.1021/i300007a005.

Pizzi A. Wood adhesives: chemistry and technology. New York: Marcell Dekker; 1983.

Pizzi A, Mittal KL. Handbook of adhesive technology. New York: Marcell Dekker; 1994

Pizzi A. Natural phenolic adhesive I: tannin. In: Pizzi A, Mital KL, editors. Handbook of adhesive technology. 2nd. ed. New York: Marcell Dekker; 2003. http://dx.doi. org/10.1201/9780203912225.ch27.

Sartori CJ, Castro AHF, Mori FA. Teores de fenóis totais e taninos nas cascas de angico-vermelho (Anadenanthera peregrina). Floresta e Ambiente 2014a; 21(3): 394-400. http://dx.doi.org/10.1590/2179-8087.061113.

Sartori CJ, Mori FA, Valle MLA, Mendes LM, Protásio TP. Rendimento gravimétrico em taninos condensados nas cascas de Anadenanthera peregrina em diferentes classes diamétricas. Cerne 2014b; 20(2): 239-244. http://dx.doi. org/10.1590/01047760.201420021512.

Vázquez G, Antorrena G, González J, Alvarez JC. Tanninbased adhesives for bonding high-moisture Eucalyptus veneers: influence of tannin extraction and press conditions. Holz als Roh- und Werkstoff 1996; 54(2): 93-97. http:// dx.doi.org/10.1007/s001070050144.

Zarin MA, Wan HY, Isha A, Armania N. Antioxidant, antimicrobial and cytotoxic potential of condensed tannins from Leucaena leucocephala hybrid-Rendang. Food Science and Human Wellness 2016; 5(2): 65-75. http://dx.doi.org/10.1016/j.fshw.2016.02.001. 